\title{
Assessment of Efficiency and Profitability of Listed Banks in Ghana
}

\author{
Dr. John Kwaku mensah Mawutor ${ }^{1} \&$ Awah Fred $^{2}$ \\ ${ }^{1}$ University of Professional Studies, Accra, Ghana \\ ${ }^{2}$ University of Professional Studies, Accra, Ghana \\ Correspondence: Dr. John Kwaku Mensah Mawutor, School of Graduate Studies, University of Professional Studies, \\ Accra, Ghana. P.O.Box 149 Legon-Accra. Tel: 233-24-328-7242. E-mail: john.mensah@upsa.edu.gh / \\ kwaku2mensah@gmail.com
}

Received: October 26, 2014

Accepted: December 10, $2014 \quad$ Online Published: December 15, 2014

doi:10.5430/afr.v4n1p164

URL: http://dx.doi.org/10.5430/afr.v4n1p164

\begin{abstract}
The Ghanaian banking industry has had both good and bad times as far as profit is concerned. However, the industry remains good, as evidened from the rising number of other banks from the continent to either merge with the indigenous banks or take over the operation of some of the local banks. In this view this; the study assessed the efficiency and profitability of banks operating in Ghana by using listed banks between the years 2006 to 2011. This quantitative study employed panel data approach using regression analysis to assess the efficiency of banks operating on the Ghana Stock Exchange. The dependent variable is profitability, comprises of return on assets and the size of the firm. The independent variable efficiency also comprises leverage ratio, liquidity ratio, credit risk ratio and profitability ratio. The main source of data employed for this research is a secondary data. The study revealed that 60.74 percent of the variation or changes in the profitability of the banks are accounted for by the independent variables such as the liquidity level, leverage, productivity, credit risk and size of the banks. This was revealed by the coefficient of determination $\left(\mathrm{R}^{2}\right)$ which shows the amount of variation in the dependent variable as being explained by the independent variables
\end{abstract}

Keywords: Efficiency, Profitability, Banking industry, Assessment

\section{Introduction}

\subsection{Introduce the Problem}

The banking sector of every economy plays a key role in fostering growth and subsequently development (Mawutor, 2014; Duca \& McLaughlin, 1990). All over the world, economies rely on the banking sector to serve as an intermediary for settlement of debts or payments between two or more parties (Mawutor, 2014). In Ghana, the banking sector is playing a number of roles. Some of these include; trade facilitation, offering letters of credit for importers, as well as serving as channels for receiving payments on behalf of exporters, and continue to serve as sources of finance for businesses both small and large (Bourke, 1989). Over the past few years, the Ghanaian banking industry has seen great changes in terms of the number of banks operating in the country. Until the recent merger between The Trust Bank and Ecobank Ghana, there were twenty six (26) banks operating in the country (now 25) (BOG, 2012). The question then remains as to why the sudden influx of so many banks into the country, hence the study focused on seven listed banks on the Ghana Stock Exchange which are HFC bank, Ghana Commercial Bank, SG-SSB, Ecobank, Cal bank, UT bank and Standard Chartered bank. This study assessed the efficiency and profitability of the banks operating in Ghana by using listed banks financial statement from 2006 to 2011. By this development; it will also mean that these banks will have to compete against each other for market share and businesses which are essential for their growth, profitability and sustainability.

Hussain and Bhatti (2010) revealed that the way banks operate has changed over the years. It can be said that such a change is eminent in view of the stiff competition in the industry as a result of the increase in the number of banks as compared to a decade ago. In a statement by the former Governor of the Bank of Ghana (BOG, 2012) it was cited that "We are in competition with banks beyond our borders and our customers are looking beyond us to what opportunities available elsewhere" (Ghana Banking Survey, 2011). This statement by the former Governor further sheds light on the impending competition in the industry and as such its effect on banks efficiency and profitability since the share of the industry will no more be concentrated amongst the few banks but rather be divided amongst the 
lot.

Industry expects have indicated that the banking industry in Ghana is higher and remain profitable, which has given rise to this sudden increase or emergence of banks from neighboring West African countries and others from the Sub-region or the African continent. Notwithstanding this challenge and the saturation of the market, the 2011 Ghana Banking Survey (GBS) has shown that industry profit before tax increased by 95 percent from GH $\phi 298.1$ million in 2009 to GH $₫ 580.3$ million in 2010 after staggering losses and weak profitability over the previous years. Such evidence re-echoes the good potentials/prospects in the industry. It is also asserted in certain quarters that the country (i.e. Ghana) is attracting a lot of investment in terms of international and reputable banks because of the generally peaceful socio-political nature/atmosphere in the country.

As part of the core business of banks, and as indicated earlier, banks serve as lending institutions that meet the needs of clients. In this country however, it is often argued that banks make lot of profit through the granting of credit/loan facilities to their customers at high interest rates or spreads. This is evident from the income composition of the banking sector as at December 2011 (Bog Financial Stability Report, 2012). The statistics from the February Financial Stability report indicate that Loans constitute a greater proportion of the income composition of banks in the country. Annually, the percentage stood at 49.4 percent, 55.3 percent, 58.7 percent, 55.9 percent, and 46.4 percent for the years; 2007, 2008, 2009, 2010, and 2011 respectively. This present situation shows that the profitability of the industry remains sound. By indication, the future prospects in terms of profitability remain good and so the banks that decided to join the fray might have looked at the terrain and saw the good prospects in it and as such are likely to remain profitable. This also means that the banks must have efficiency as their hallmark since profitability is likely not to be achieved without efficient and prudent management.

\subsection{Problem Statement}

The February 2012 financial stability report released by the Bank of Ghana (BOG) shows that profit of banks in terms of return on assets (ROA) as at the end of the year 2011 dipped even though some individual banks released remarkable financial year profitability results. Coupled with this, the profitability indicators for the banking industry showed inconsistent earnings performance over the six year period of the survey (BoG Financial Stability Report, 2011). For instance, the profitability ratio of the banking sector dropped to a low of 9.8 percent in 2009 from a peak of 19 percent in 2006 following a year-on-year deterioration in profit. Though strides were made by increasing it to 17.8 percent as at December 2011 from the 9.8 percent, this increment can be described as relatively marginal as it constituted only a 3.2 percent change. The same situation was with the percentage of the return on assets (ROA) ratio of the industry.

It must be mentioned however that despite current progression or positive developments in terms of income, the banks are facing some challenges which go a long way to negatively affect their profitability. It is therefore crucial to ascertain and assess these factors or reasons that hinder the profitability of these banks since their sustenance is critical to the economic stability of the country. Hence, this study seeks to assess the efficiency and profitability of banks in Ghana by using listed banks on the Ghana Stock Exchange (GSE).

\subsection{Objectives}

The main objective of this study was to assess the efficiency and profitability of banks operating in Ghana by using listed banks between the years 2006 to 2011. In achieving this broad objective, the following specific objectives have been put forward.

1. To ascertain whether the credit risk position of the banks has any influence on their profitability

2. To find the relationship between bank efficiency and profitability

3. To find out if the leverage levels of the banks has any effect on their profitability

4. To determine the impact that bank size has on profitability of the banks

5. Which factors affect the profitability of the listed banks in Ghana?

\subsection{Research Questions}

In view of the above, the followings research questions are formulated

1. Is there a significant relationship between credit risk and profitability

2. Is there a positive relationship between efficiency and profitability

3. Is there a positive relationship between bank size and profitability 


\section{Methodology}

This quantitative study employed panel data approach using regression analysis to assess the efficiency of banks operating on the Ghana Stock Exchange. The dependent variable is profitability, comprises of return on assets and the size of the firm. The independent variable efficiency also comprises leverage ratio, liquidity ratio, credit risk ratio and profitability ratio. The target population of this study are the listed banks on the Ghana Stock Exchange (GSE) which comprises of seven banks; Ecobank, Ghana Commercial bank, HFC bank, Standard Chartered bank, SG-SSB bank, Cal bank and UT bank. The sample for this research consisted of all the listed banks on the Ghana Stock Exchange, which are: Ecobank, Cal Bank, Ghana Commercial Bank, HFC Bank, Standard Chartered Bank, SG-SSB, and UT Bank. Hence, the sample comprised of these seven listed banks on the GSE studied over a period of time. The main source of data employed for this research is a secondary data. These were the financial statements of the listed banks extracted to perform the research analysis

\subsection{Analysis of Data}

The profitability level or the profitability of the banks were assessed or measured using the Return on Assets (ROA) ratio. According to Peirson et al. (1990), the aim of profitability ratios is to measure the effectiveness of management in using a company's resources to generate returns for shareholders. In particular, the ROA measures the overall effectiveness of management in making use of the firms' available assets to generate profits. This is often/sometimes used as a firm efficiency measure.

The variables that shall constitute the independent variables are explained below.

\subsection{Size}

The size of a firm affects the firm's profitability. Notwithstanding, the actual or real relationship is mixed (Becker-Blease et al., 2010). Thus whether the effect is positive or negative have produced mixed results. As noted by Becker-Blease et al. (2010), one cannot draw a sharp conclusion or say with conviction without any empirical evidence as far as the relationship that exist between the size of a firm and its profitability is concerned. This argument is on the basis that the relation between firm size and profitability can be firm specific. It therefore appears that making generalizations in this regard can be weary. This necessitated the argument by Becker-Blease et al. (2010) that there is no pre-assumption reason that large firms are naturally more profitable than smaller ones. Hence, in this study, the size of the banks was assessed to find out if their size is influences their profitability. This was measured by their total assets. Following the above, a regression model was formulated as follows:

$$
R O A_{i}=a_{0}+b_{1} L I Q_{i}+b_{2} C R_{i}+b_{3} P_{R O D_{i}}+b_{4} L E V_{i}+b_{5} S I Z E_{i}+\varepsilon_{i}
$$

Where ROA is return on assets (dependent variable), LIQ is liquidity, CR is credit risk, PROD is productivity, and LEV is leverage.

$a_{0}$ is the intercept of the equation, $b_{1} t o b_{5}$ are the coefficients of the respective variables and $\varepsilon_{i}$ is the error term.

\subsection{Liquidity}

Liquidity ratios in general are indications of how efficient or well-organized a firm is to meet its short term obligations when they are due. This is a clear indication that the firm can settle its immediate and future obligations and still keep its operations as efficient as possible (Mawutor, 2014). In this study, one liquidity ratio was used; which is the current ratio. The concept behind this ratio is to ascertain whether a firm's short-term assets are readily available to pay off its short-term liabilities. Thus in theory, the higher the ratio the better or efficient the firm is. This is given as:

\section{$\frac{\text { Currentissets }}{\text { Currentiabilities }}$}

\subsection{Credit Risk}

The banks' credit risk level as indicated is a proxy for Bad or non-performing loans to Total loans. Cooper, et al (2003), in their credit risk level, revealed changes in the strength of a bank's loan portfolio, which may affect the performance/profitability of the bank. Duca and McLaughlin (1990), believe that any discrepancy in bank profitability for the most part are attributable to variations in credit risk. According to the author, an increased in credit risk will normally expose the bank to a decrease in the bank's profitability. Very efficient and more profitable banks are those that have lower non-performing loans in relation to their total loans. Hence, the banks' credit risk level was ascertained to ascertain its impact on their profitability. Here, the lower the ratio, the better. This was be 
measured as:

\section{Badornon-performinglown \\ Totalloans}

\subsection{Efficiency and Productivity}

A number of factors account for the efficiency of banks (Mawutor, 2014). Some of these factors may include the liquidity ratio of the bank, the credit risk ratio of the bank, the productivity ratio of the bank and the leverage ratio of the bank. It is also revealed that firm performance as indicated by firm profitability has something to do with organization efficiency. This is often mentioned in the realm of firm profitability and corporate governance (Shenand Lin 2010). Shenand Lin (2010) is of the view that better managed firms have the potential of making substantial profits, this emanates from the fact that, when a firm has less interruptions from external and ownership structures, the firm is likely to grow and perform well. Hence, firms that are faced with less bureaucracies and less external interferences earn more profits and perform well. This implies that operational efficiency is a must for improving the profitability of the bank. The bank efficiency ratio was the calculated on its productivity. This is the cost to revenue ratio. It is given as:

\section{$\frac{\text { Non-interestexpensas }}{\text { OperatingRevenue }}$}

The non-interest expenses level reflects its efficiency in converting inputs into revenue or profit. It is expected that an efficient bank will have a lower ratio and a less efficient one

will have a higher ratio.

\subsection{Leverage}

Berger (1995), on his view argued that even though leverage (capitalization) has been demonstrated to be important in explaining the performance of financial institutions, its impact on bank profitability is ambiguous. As lower capital ratios suggest a relatively risky position, one might expect a negative coefficient on this variable. The author further stated that an increase in capital may raise expected earnings by reducing the expected costs of financial distress, including bankruptcy. Nonetheless, it could be the case that higher levels of equity would decrease the cost of capital, leading to a positive impact on bank profitability (Molyneux, 1993). It was established in financial theory that debt brings about discipline and promotes efficiency of firms. This ideology is emphasized owing to the fact that a firm that takes on debt will have to honor its debt obligations which calls for some level of efficiency on the part of managers as it comes with its associated risks. It is also a measure of firm financial health. This will be measured by the debt to equity ratio. Or

$$
\frac{\text { TrotalDebt }}{\text { TotalEquty }}
$$

\section{Results}

\subsection{Model Acceptance Analysis}

One of the traditional ways of assessing the performance or well-being of a regression model is the coefficient of determination $\left(\mathrm{R}^{2}\right)$. This shows the amount of variation in the dependent variable as being explained by the independent variables. The higher the value the better and vice-versa. From the results in table 1, it is observed that, the $\mathrm{R}^{2}$ value is 0.6074 or $60.74 \%$. This means that 60.74 percent of the variation or changes in the profitability of the banks are accounted for by their liquidity, leverage, productivity, credit risk and size. The rest is however explained by other factors which were not captured. It can also be observed that there is an adjusted $\mathrm{R}^{2}$. Though this has the same meaning as the non-adjusted, the differences come in because the adjusted $\mathrm{R}^{2}$ takes into consideration the degree of freedom which depends on the number of independent variables in the model. From the table (table 1) once more, it is observed that adjusted $\mathrm{R}^{2}$ has a lower value due to the degree of freedom. Though it is lower, its value is not so low to render the power of our regression model because it still explains 53.97 percent of the variations in profitability as far as the independent variables are concerned. The f-value is another way to assess a regression model. This reveals the statistical significance of the whole model. From the table, it is observed that the F-value is 8.97 . This corresponds to a p-value of 0.000 for easy reading. What this means is that all the independent variables together, makes the model statistically significant at the 0.01 significance level. In other words, it can be established that the model is significant or good with 99 percent confidence level. 
Table 1. Model Summary

\begin{tabular}{|l|l|l|l|}
\hline F-value & p-value & R2 & Adj. R2 \\
\hline 8.97 & 0.000 & 0.6074 & 0.5397 \\
\hline
\end{tabular}

\subsection{Independent Variables}

Liquidity as an Indicator of Firm Profitability

Liquidity of a firm plays a significant role as far as the solvency of the firm is concern. This is eminent since it shows how well a firm can settle its short term debts. Firms in financial trouble will find it difficult to cover their debts as they come due and the opposite is true for healthier firms. In essence, it tells how much there are assets to take care of liabilities. In this study, the liquidity of the firms was measured by the ratio of current assets to current liabilities. From table 2, there is a positive relationship between firm profitability and the liquidity of the firm. Thus, profitable firms are those that are liquid. The coefficient (0.0038) means that a unit increase in the liquidity of the banks will lead to a 0.38 percent increase in their profitability. Having said this, the ratio in this study is statistically insignificant at both the 5 percent and 10 percent significance levels (i. e. $0.343>0.05$ and 0.10 ). This means that per our study, profitability of banks is not affected or influenced by their liquidity.

\subsection{Credit Risk}

Credit risk is another instrumental variable as far as bank profitability and solvency are concern (Arnold, 200). Credit risk has caused many bank failures and bankruptcies in the past notably the current global credit crunch. Banks with high credit risk profile are termed as highly volatile (Amato, 1997). Also, owing to the huge loss-reserve provisions that banks will have to make for expected credit losses, they are very critical about this as it lowers and eats into their profit margins. It is hence postulated that more efficient and profitable firms are those that are less risky credit-wise (Basel, 1999). From our study (see table 2), there is a negative statistical significant relationship between firm profitability and its credit risk at the 0.10 significance level $(0.071<0.10)$. Meaning the higher the credits risk of the bank, the lower its profitability. The coefficient of -0.0064 signifies that a unit increase in the credit risk of the banks will result in a 0.0064 Ghana Cedi reduction in their profits.

\subsection{Productivity}

Productive firms are those that generate enough revenue to cover their expenses. In this study, the productivity of the banks was measured by the interest expense to the operating income/revenue. By this, less productive firms will have higher ratios as compared to their productive counterparts. The results met the expectation that an efficient bank will have a lower ratio and a less efficient one will have a higher ratio hence the negative relationship with profitability. This outcome means that a unit increase in the ratio will result in a 1.05 percent reduction in the profitability of the firms. The ratio is as well statistically significant at the 0.01 significance level. This is because the p-value from the table is less $(0.000)$ than the one at the 0.01 significance level. It is also significant at both the five percent and ten percent significance levels.

\subsection{Leverage}

This ideology is emphasized owing to the fact that a firm that takes on debt will have to honor its debt obligations and so that will call for some level of efficiency on the part of managers as it comes with its associated risks. It is also a measure of the firm's financial health. Notwithstanding, highly leveraged firms are termed risky and are also likely to report lower profits. The results of the study show that leverage is statistically significant or important as far as the profitability of a bank is concerned. With a p-value of 0.003 , we can say with 99 percent confidence that leverage is crucial to firm profitability and that banks that carry on too much debt are 99 percent likely to record lower profits. In essence, a-unit increase in the debt ratio will lead to a 0.02 percent reduction in the profitability of the banks. Our results corroborate the findings of Asimakopoulos et al. (2009) who found a negative significant relationship between leverage and profitability.

\subsection{Size}

The sizes of the banks in this study were measured by their total assets. From the results, the size of the banks is not statistically significant in relation to their profitability at both the 10 percent and 5 percent significance levels (i. e. $0.747>0.05 ;>0.10$ ). Thus, profitability of the banks is not influenced by their size. This finding is similar to the findings of Micco et al. (2007) who showed that there is no significant association between bank size and the Return on Assets (ROA) of the banks. On the issue of the sign of the coefficient, Micco et al. (2007) argue that a positive relationship is appropriate. Amato and Wilder (1985) however oppose this view sighting that a negative relationship 
between firm size and profitability is presented within the theory of the firm, which focuses on alternative theories of a firm's motivation. Narrowing the argument down to the significance of the variable, Barros et al. (2007) showed that bigger and more diversified banks are more likely to perform poorly. Similarly, Becker-Blease et al. (2010) examined the relation between firm size and profitability and found that there is no relationship between profitability and size. This interesting point from these findings is that, there is no straight forward say on how much size influences firm profitability. This could be due to the different settings in which these studies are conducted

Table 2. Independent Variables used in the Regression Analysis

\begin{tabular}{lclcc}
\hline Variables & Coefficient & Std. Error & t-value & p-value \\
\hline Liquidity & .0037649 & .0039013 & 0.97 & 0.343 \\
Credit Risk & -.00636 & .0033985 & -1.87 & 0.071 \\
Productivity & -.0104952 & .0017594 & -5.97 & 0.000 \\
Leverage & -.0015147 & .0046449 & -0.33 & 0.003 \\
Size & .0674112 & .0408628 & 1.65 & 0.110 \\
\hline
\end{tabular}

\section{Discussion}

The main focus of the study was to examine the efficiency and profitability of listed banks operating in Ghana. To achieve this broader objective, the study aimed at achieving the following specific objectives: To ascertain whether the credit risk position of the banks has any influence on their profitability; To find the relationship between bank efficiency and profitability; To find out if the leverage levels of the banks has any effect on their profitability; To determine the impact that bank size has on profitability of the banks; and to find out the factors that affect the profitability of the listed banks in Ghana. Methodologically, the study employed the quantitative methods where financial statements of the listed banks on the Ghana Stock Exchange (GSE) served as the main data source. In all, financial statements of seven (7) listed banks from 2006 to 2011 were purposively sampled for the analysis. This formed the secondary data source for the research. In the analysis, regression model and correlation were adopted to assist in finding answers to the research questions. The outcome of the data analysis produced consistent results with literature.

The finding of the study showed that 60.74 percent of the variation or changes in the profitability of the banks are accounted for by the independent variables such as the liquidity level, leverage, productivity, credit risk and size of the banks. This was revealed by the coefficient of determination $\left(\mathrm{R}^{2}\right)$ which shows the amount of variation in the dependent variable as being explained by the independent variables. That is the higher the value of $\mathrm{R}^{2}$ the better and vice-versa and in this case the value for $\mathrm{R}^{2}$ is 0.6074 or $60.74 \%$. It was also found that credit risk, productive, and leverage of the banks has a negative impact on the profitability of the banks while liquidity and the size of the banks also have a positive relationship with the profit level of the banks. However from the regression analysis it was realize that at $5 \%$ and $10 \%$ significance level, all the independent variables thus: liquidity; credit risk; productive; leverage; and size of the bank are statistically significant in influencing the profitability of the banks.

From the results of the regression, it is obvious that productivity indeed has a significant influence on the profitability of banks. With reference to table 4.1, productivity showed a clear level of significance by reporting a p-value of 0.00 . With this background, the study can conclude with $95 \%$ confidence level that productivity plays a major factor in the level of bank profitability.

Another variable that was very crucial in this research for determining the profit level of the banks is leverage. From the result it was also revealed that leverage is statistically significant or important as far as the profitability of a bank is concerned. With a p-value of 0.003 , it can be stated that, with 95 percent confidence that leverage is vital to firm profitability and that banks that carry on too much debt are 95 percent likely to record lower profits. In essence, a unit increase in the debt ratio will lead to a 0.03 percent reduction in the profitability of the banks. Again it is also realized from the study that (see table 4.2), there is a negative statistical significant relationship between firm profitability and its credit risk at 0.10 significance level $(0.071<0.10)$. This means that the higher the credit risks of the bank, the lower its profitability. The coefficient of -0.0064 signifies that a unit increase in the credit risk of the banks will result in a 0.0064 Ghana Cedi reduction in their profits. However, the result as shown in table 4.2 indicated that there is a positive relationship between firm profitability and the liquidity of the banks. Thus, profitable firms are those that are liquid. From the coefficient (0.0038) point of view it can be stated that a unit increase in the liquidity of the banks will lead to a 0.38 percent increase in their profitability. Having said this, the ratio in this study is statistically insignificant at both the 5 percent and 10 percent significance levels (i. e. $0.343>$ 0.05 and 0.10 ). This means that per the study, profitability of banks is not affected or influenced by their liquidity.

One other independent variable from the result that was not statistically significant in relation to their profitability at 
both the 10 percent and 5 percent significance levels is size (i. e. $0.747>0.05 ;>0.10$ ). Thus, profitability of the banks is not influenced by their size.

But in all it can be observed from the overall results of the regression model, that the coefficient of determination $\left(\mathrm{R}^{2}\right)$ which shows the amount of variation in the dependent variable as being explained by the independent variables is 0.6074 or $60.74 \%$ which we interpreted to mean that 60.74 percent of the variation or changes in the profitability of the banks are accounted for by their liquidity, leverage, productivity, credit risk and size. This means that all the independent variables as stated above have a significant influence on the profitability of the banks (dependent variable) with an overall p-value of 0.000 and an $f$-value of 8.97 which also explains the statistical significance of the whole model. In other words, considering the main objective of this study which aimed at assessing the efficiency and profitability of banks operating in Ghana using only listed banks on the Ghana stock exchange, it can be conclude with 100 percent confidence that it is only leverage, productivity, and credit risk that has a very significant influence on the profitability of the bank.

\section{References}

Amato, L., \& Wilder, R. P. (1985). The Effects of Firm Size on Profit Rate in U.S .Manufacturing. Southern Economics Journal, 52, 181-190. http://dx.doi.org/10.2307/1058913

Arnold, G. (2008). Corporate Financial Management.4th edition. Prentice Hall. Essex.

Asimakopoulos, I., Samitas, A. and Papadogonas, T. (2009). "Firm-specific and economy wide determinants of firm profitability: Greek evidence using panel data", Managerial Finance, Vol. 35, No. 11, pp. 930-939. http://dx.doi.org/10.1108/03074350910993818

Bank of Ghana Monetary Policy Report, Financial Stability, Vol. 5, No.1/2012, February 2012.

Basel, 1999 ; IAIS. (2003). Credit risk management system of a commercial bank in Tanzania.

Becker-Blease, J. R., Kaen, F. R., Etebari, A. and Baumann, H. (2010). "Employees, firm size and profitability in U.S. manufacturing industries", Investment Management and Financial Innovations, Vol. 7, Issue 2, pp.7-53.

Berger, A., Hanweck, D., Humphrey, D. (1987). Competitive viability in banking: Scale, scope, and product mix economies. Journal of Monetary Economics 20 (3), 501-520. http://dx.doi.org/10.1016/0304-3932(87)90039-0

Berger, A.N. (1995a). The profit-structure relationship in banking: tests of market-power and efficient-structure hypotheses. Journal of Money, Credit, and Banking 27, 404-431. http://dx.doi.org/10.2307/2077876

Berger, A. N., Humphrey, D. B. (1994). Bank scale economies, mergers, concentration, and efficiency: The U.S. experience. The Wharton Financial Institutions Center, Working Paper 94-25.

Cooper, M., Jackson, W., \& Patterson, G. (2003). Evidence of predictability in the cross section of bank stock returns. Journal of Banking and Finance 27, 817-850. http://dx.doi.org/10.1016/S0378-4266(01)00263-1

Duca, J., \& McLaughlin, M. (1990). Developments affecting the profitability of commercial banks. Federal Reserve Bulletin, 477-499.

Ghana Banking Survey (GBS). (2010).

Ghana Banking Survey (GBS). (2011).

Gilbart J. W. (1847). The History, Principles And Practice Of Banking, London, George Bell and Sons.

Gitman, L. (1989). Basic Managerial Finance.2nd edition. New York: Harper \& Row.

Glasow, P. A. (2005). "Fundamentals of Survey Research", MITRE Washington C3 Center McLean, Virginia, MP 05W0000077, April, retrieved from http://www.mitre.org.

González, F. (2009). "Do equity investments affect banks' profitability? .Evidence from OECD Countries" pp. 1-27.

Golin, J. (2001). The Bank Credit Analysis Handbook: A Guide for Analysts, Bankers and Investors. John Wiley \& Sons (Asia) Pre Ltd.

Goski Alabi. (2009). General Guidelines For Writing A Research Report.

Grygorenko O. (2009). Effects of Price Setting on Bank Performance: The case of Ukraine, Kyiv School of Economics, Ukraine.

Guru B.K., Staunton J. \& Balashanmugam B. (1999). "Determinants of Commercial Bank Profitability in Malaysia", Paper presented at the 12th Annual Australian Finance and Banking Conference, Sydney, Australia, 16-17 December.

Hassan, M. K., \& Bashir, A. H. M. (2003). Determinants of Islamic banking profitability. Paper presented at the 10th ERF Annual Conference, Morocco, 16-18 December. 
http://libguides.library.cqu.edu.au/content_mobile.php?piud=9872

http://legal-dictionary.thefreedictionary.com//dict.aspx?rd=1\&word=Bank+duties

Hussain, H \& Bhatti, G.A, (2010). Evidence on Structure Conduct Performance Hypothesis in Pakistani Commercial Banks, International Journal of Business and Management, Vol. 5, No. 9, pp: 174-187.

Jennifer Williams (2011). What is Research Methodology.

Keeton, W.R. \& L. Matsunaga. (1985). "Profits of commercial banks in Tenth District states". Economic Review of Federal Reserve Banks of Kansas City, June 3-22.

Kotšina, S. \& Hazak1, A. (2012). "Does Investment Intensity Impact Company Profitability? A Cross-Country Empirical Study", 2012 2nd International Conference on Economics, Trade and Development IPEDR, vol.36. pp. 157-161.

Kosmidou K. Pasiouras F. Tanna S. (2005). Determinants of Profitability of Domestic UK Commercial Banks: Panel Evidence from the Period 1995-2002, Website: http://repec.org/mmfc05/paper45.pdf (Accessed: January 30, 2011).

Maness, T. S. \& Zietlow, J.T. (2005). Short-term Financial Management., Ohio: South-Western/Thomson Learning.

Matarazzo, D. C. (2003). AnáliseFinanceira de Balanços. São Paulo: Atlas, 2003.

Mensi S. \& Zouari A. (2010). Efficient Structure versus Market Power: Theories and

Empirical Evidence, High School of Business of Tunis (ESCT), Manouba University Higher Business Studies Institute (IHEC), University of The 7th November at Carthage

Micco, A., Panizza, U., Yanez, M. (2007). Bank ownership and performance. Does politics matter? Journal of Banking and Finance 31 (1), 219-241. http://dx.doi.org/10.1016/j.jbankfin.2006.02.007

Miller, S. M. \& Noulas, A. (1997). Portfolio Mix and Large Bank Profitability in the USA.Applied Economics 29(4): 505-512. http://dx.doi.org/10.1080/000368497326994

Molyneux, P. \& Thornton, J. (1992). "Determinants of European Bank Profitability: A Note". Journal of Banking and Finance, 16: 1173-1178. http://dx.doi.org/10.1016/0378-4266(92)90065-8

Herbst, G. \& Roberts-Lombard, M. (2010). "An investigation into the impact of the usage of debt on the profitability of small and medium enterprises in the Buffalo city municipality, South Africa", African Journal of Business Management, Vol. 4, No. 4, pp. 373-381,

Obert, M. \& Olawale, F. (2010). "Does debt really matter on the profitability of small firms? A perspective on small manufacturing firms in Bulawayo, Zimbabwe", African Journal of Business Management, Vol. 4, No. 9, pp. 1709-1716.

Peavler, R. (2011). "Inventory Investment and Maximizing Profit: Analyze your Dead, Slow Moving, and Productive Inventory", About.com Guide.

Peirson, G., Bird, R. \& Howard, P. (1990). "Business Finance", $5^{\text {th }}$ Edition, McGraw-Hill,Sydney.

Peltzman, S. (1977). "The Gains and Losses from Industrial Concentration", Journal of Law and Economics, Vol. 20, No. 2, pp. 229-263. http://dx.doi.org/10.1086/466902

Perobelli, F. F. C., Pereira, J. F. \& David, M. V. (2006). RelaçãoLiquidez-Retorno:Existiriatambémuma "Estrutura de Liquidez" Ideal paracadaPerfil de Empresa?EnAMPAD.1-16. http://www.anpad.org.br/enanpad/2006/dwn/enanpad2006-ficb-2510.pdf

Rhoades, S. A. (1985). Market Share as a Source of Market Power: Implications and Some Evidence. Journal of Economics and Business 37(4): 343-363. http://dx.doi.org/10.1016/0148-6195(85)90027-X

Rose P. \& Hudgins S. (2005). Bank Management and Financial Services, 6th Edition, New York: McGraw-Hill.

Sabo, B. (2007). An Assessment of the Determinants of the Nigerian Banking Industry Profitability: Using Panel Evidence from Nigerian Commercial Banks. The Information Manager Vol. 7 (2) 2007.

Sanni, M.R. (2006). Consolidated Accounts Made Simple. Ilaro, Ogun State, Nigeria, IPS Educational Press, 178-180.

Shen, W. \& Lin, C. (2010). "Firm Profitability, State Ownership, and Top Management Turnover at the Listed Firms in China: A Behavioral Perspective".

Shim, J. K. \& Siegel, J. G. (2000). Financial Management.2nd edition; Barron’s.

Umole, M. (1983). Monetary and Financial system in Nigeria, London, A.I.B Publishers. 